\title{
Sexually transmitted pathogens in pregnant women in a rural South African community
}

\author{
N O'FARRELL, * A A HOOSEN, $†$ A B M KHARSANY, $†$ J VAN DEN ENDE $\dagger$ \\ From the *Ngwelezana Hospital, Empangeni, Natal, and the †Department of Medical Microbiology, Faculty of \\ Medicine, University of Natal, Durban, South Africa
}

SUMMARY One hundred and ninety three consecutive pregnant women attending peripheral antenatal clinics attached to Ngwelezana Hospital, Empangeni, Kwa-Zulu, were examined for evidence of sexually transmitted pathogens. The following incidences were found: Trichomonas vaginalis $49 \cdot 2 \%$ (95), Candida spp 38.3\% (74), Chlamydia trachomatis $11 \cdot 4 \%$ (22), Gardnerella vaginalis $6 \cdot 2 \%$ (12), Neisseria gonorrhoeae $5 \cdot 7 \%$ (11), positive syphilis serology results $11.9 \%$ (23), hepatitis B surface antigen $4.1 \%$ (eight). No woman had antibody to human immunodeficiency virus (HIV). Dyskaryotic smears were found in 20 (10.4\%). Human papillomavirus (HPV) was detected cytologically in $11(5 \cdot 7 \%)$.

The range of sexually transmitted pathogens found in this rural community was similar to that found in urban groups studied in South Africa.

In rural areas where government resources and health budgets are limited, services for sexually transmitted diseases (STDs) are generally integrated into the primary health care system with problem cases being referred to outpatient departments of peripheral hospitals. Laboratory facilities are limited, and microbiological investigation of individual patients is therefore rarely possible. For correct management, particularly in cases where a clinical diagnosis is not obviously apparent, local studies may provide epidemiological and microbiological data regarding current disease patterns. Recent major changes in Africa include an increase in penicillinase producing Neissera gonorrhoeae to $87 \%$ south of the Sahara and the emergence of tetracycline resistant Haemophilus ducreyi. ${ }^{1}$

Specialised centres have been suggested for providing expertise in clinical, laboratory, epidemiological, and soeial science skills related to control. Treatment protocols may be developed and updated for rural health care providers. Treatment schedules may, however, be resistant to change. In many rural areas STDs have been regarded as virtually one disease entity and uniformly treated with penicillin injections and tetracycline tablets. The widespread belief that

Address for reprints: Dr Nigel O'Farrell, King Edward VIII Hospital, Congella, Durban, South Africa

Accepted for publication 19 March 1989 parenteral treatment is still the best is often reinforced by paramedical and nursing staff.

Antenatal attenders are well established as patients providing comparative STD data. Few rural studies have been performed in Africa and none in South Africa. In this study we investigated the carriage of sexually transmitted pathogens in antenatal attenders at three rural health centres in Kwa-Zulu, South Africa.

\section{Patients and methods}

Kwa-Zulu, originally part of Natal (fig), is a self governing homeland of South Africa with a population of five million. The yearly per capita expenditure on health is US\$12. ${ }^{2}$ Antenatal care is undertaken at peripheral clinics by qualified midwives, rarely with a doctor in attendance.

We investigated for sexually transmitted pathogens 193 consecutive attenders at three peripheral township clinics (Enselini, Esikhawini, and Ngwelezana), who had not received antibiotics in the previous two weeks. The clinics were situated within a 50 kilometre radius of Ngwelezana Hospital, Empangeni, the main referral hospital for northern Kwa-Zulu and the study was completed in one week during June 1987.

After each pregnant woman had given informed consent and had a initial interview with a midwife who completed a questionnaire, she underwent a general antenatal examination and then a vaginal examination using a sterile unlubricated Cusco's speculum. About 
$0.1 \mathrm{ml}$ vaginal secretion or discharge was aspirated, using a sterile polyethylene transfer pipette, and mixed in $1 \mathrm{ml}$ sterile normal saline. A few drops of the mixture were used to prepare a wet mount, and about $0.5 \mathrm{ml}$ was inoculated into a modified Diamond's medium $^{3}$ for the cultivation of Trichomonas vaginalis.

Cotton tipped swabs were used to collect secretions from the posterior fornix, which were inoculated at the bedside on Sabouraud's agar to cultivate yeasts, and on human blood agar to isolate Gardnerella vaginalis. ${ }^{4}$

Endocervical swabs were collected for inoculation on Modified New York City (MNYC) medium ${ }^{5}$ for the isolation of $\mathrm{N}$ gonorrhoeae and to prepare slides for direct immunofluorescence according to the manufacturer's instruction (Microtrak, Syva) to detect Chlamydia trachomatis. An endocervical Papanicolaou smear was also prepared. Swabs were taken from the urethra and rectum and plated at the bedside on MNYC medium. About $10 \mathrm{ml}$ venous blood was collected from each patient for serological testing for syphilis and infection with hepatitis B, and human immunodeficiency virus (HIV).

\section{PROCESSING SPECIMENS}

The wet mount preparation was examined by microscope at the bedside within 10 minutes of collection. MNYC medium agar, human blood agar, and modified Diamond's medium tubes were placed immediately into candle extinction jars. These and the

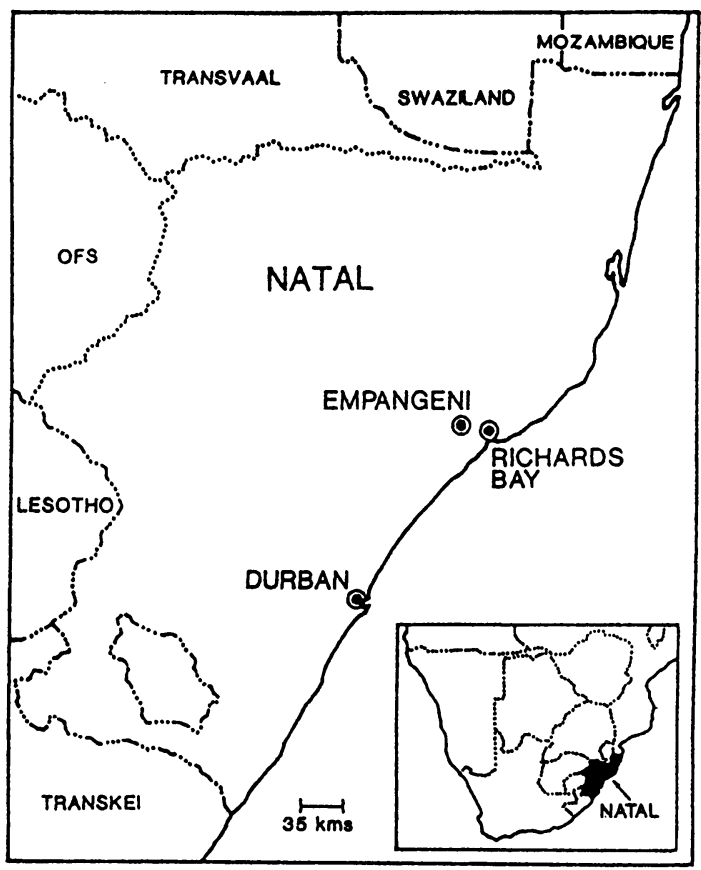

Figure Map of Natal and neighbouring areas.
Sabouraud's agar plates were transferred to an incubator at the local hospital within 4-6 hours of collection and incubated overnight at $36^{\circ} \mathrm{C}$ after which they were transferred to the microbiology laboratory in Durban, 160 kilometres away, where further investigations were performed.

$N$ gonorrhoeae, Candida spp and $G$ vaginalis were identified by conventional laboratory methods. The modified Diamond's medium was examined daily for seven days for motile trichomonads.

\section{SEROLOGY}

Serum samples were tested for syphilis by the rapid plasma reagin (RPR) test (Macrovue RPR card test, BBL Microbiology Systems, Maryland, USA) and the $T$ pallidum haemagglutination assay (TPHA) (Fujirebio, Tokyo, Japan), for hepatitis B surface antigen $\left(\mathrm{HB}_{8} \mathrm{Ag}\right.$ ) by a radioimmunoassay (Ausria kit, Abbott) and for antibody to human immunodeficiency virus (HIV) by a recombinant HIV I enzyme linked immunosorbent assay (ELISA) kit (Abbott Diagnostics, Weisbaden-Delkenheim, West Germany).

\section{Results}

All 193 participants were Zulus. Their average age was 25.6 (range 15-42) and most (133, 69\%) were unmarried. Their average age at first pregnancy was 19.2 (range 15-41). Sixty nine were primigravid women, 41 were pregnant for the second time, 30 for the third, 20 for the fourth, and 33 for the fifth time or more.

On questioning, 102 women stated that they currently had a vaginal discharge and 17 that they had had an episode of genital ulceration in the past. On examination, however, only one had a clinically apparent genital ulcer, and no genital warts were detected.

\section{SEXUAL BEHAVIOUR QUESTIONNAIRE}

The average age at first sexual intercourse was 16.7 (range 13-28). Most (190) of the women had had one to five, and three had had six to 10 , lifetime sexual partners. Only three had engaged in oral sex practices.

\section{CONTRACEPTION}

The most common form of contraception used had been the depot injection of progesterone ( 49 women), the oral contraceptive pill had been used by 27 , four had used an intrauterine contraceptive device, and four stated that their partners had used condoms. Most $(125,65 \%)$ had never used any form of contraception.

Table 1 shows the incidences of the various micro- 
Table 1 Micro-organisms identified in genital specimens from 193 pregnant women

\begin{tabular}{lcc}
\hline Organisms & No & $\%$ Positive \\
\hline Trichomonas vaginalis & 95 & $(49 \cdot 2)$ \\
Candida spp: & 74 & $(38 \cdot 3)$ \\
C albicans & 52 & $(26 \cdot 9)$ \\
C glabrata & 14 & $(7 \cdot 3)$ \\
Other Candida spp & 8 & $(4 \cdot 2)$ \\
Saccharomyces cerevisiae & 11 & $(5 \cdot 7)$ \\
Gardnerella vaginalis & 12 & $(6 \cdot 2)$ \\
Neisseria gonorrhoeae & 11 & $(5 \cdot 7)$ \\
Chlamydia trachomatis & 22 & $(11 \cdot 4)$ \\
\hline
\end{tabular}

organisms that were sought by lower genital tract sampling.

$T$ vaginalis was detected in about half $(95)$ of the women examined. In 71, the parasite was identified by its characteristic morphology and movement in wet smear preparations, and in 24 the organism was detected by culture only.

Candida spp were cultured from high vaginal swab specimens for 74 women. The most common was $C$ albicans (from 52), C glabrata was isolated from 14, and other Candida species from eight. The remaining 11 yeast isolates were identified as Saccharomyces cerevisiae.

$G$ vaginalis was cultured from high vaginal swab specimens from 12 women.

$N$ gonorrhoeae was isolated from 11 women. The site of isolation was the cervix in nine women, the urethra in five, and the rectum in four. In two women the rectum was the sole site of isolation. Of the 11 women with gonorrhoea, three were infected with penicillinase producing (PPNG) strains.

$C$ trachomatis was detected by direct immunofluorescence in 22 women.

Of the 102 women who complained of a vaginal discharge, 82 yielded at least one recognised vaginal pathogen, 39 yielded no pathogen, and 76 harboured more than one recognised vaginal pathogen.

\section{Discussion}

Rural communities are generally more conservative than their urban counterparts, and in Kwa-Zulu this is probably due in part to the influence exerted by missionary teaching; in some areas mission hospitals still provide the only available medical expertise. Premarital sexual intercourse is strongly discouraged, particularly by heads of families who may realise higher bride prices (lobola) for virgin daughters. Among engaged couples, however, the practice of intracrural intercourse (ukosoma) is accepted. Marriage may take place when a traditional lobola of eleven head of cattle is paid to the bride's father.
Polygamy is practiced by older wealthier men who are able to afford further lobola payments.

The relatively low numbers of lifetime sexual partners in our patients $(98.5 \%$ having had $1-5$ sexual partners in their lifetime) and the high incidence of sexually transmitted pathogens isolated in this study suggest that male migrant workers returning from urban areas act as the main source contacts for STD in this community.

The incidence of $5.7 \%$ for gonorrhoea was lower than the finding of $10 \%$ in a previous local urban study. ${ }^{6}$ Incidence of gonorrhoea in other rural African antenatal clinic studies range from $1 \%$ in the $\mathrm{Gambia}^{7}$ to $40 \%$ in Uganda, ${ }^{8}$ with $22 \%$ in Cameroon. ${ }^{9}$ Urban incidence range from $3.9 \%$ in Ghana ${ }^{10}$ to $17.8 \%$ in Zimbabwe, ${ }^{11}$ and $11 \%$ elsewhere in South Africa. ${ }^{12}$ The incidence of $(27 \%, 3 / 11)$ PPNG strains recorded in this study was in keeping with figures of $16-25 \%$ for $N$ gonorrhoeae isolates from STD patients in Durban (KD Coetzee et al infectious diseases and STD congress, Durban 1987) ${ }^{13}$ First line treatment against PPNG strains has been recommended when levels reach $5 \%,{ }^{14}$ and our figures would justify changing the treatment for a rural environment at the same time as the urban area.

The importance of $C$ trachomatis in Africa is now well established, with urban antenatal incidences of $6.9 \%$ in the Gambia, ${ }^{15} 10.3 \%$ in Nigeria, ${ }^{16} 29 \%$ in Kenya, ${ }^{17}$ and $7-10 \%$ in South Africa (AA Hoosen et al and HG Fehler et al infectious diseases and STD congress, Durban 1987). In the Gambia chlamydial infection has been found in $3 \%$ of rural antinatal clinic patients. ${ }^{7} C$ trachomatis was isolated in $73 \%$ of patients with pelvic inflammatory disease (PID) in Bloemfontein, ${ }^{18}$ but gonorrhoea is more often implicated locally. $N$ gonorrhoeae has been cultured in $57 \%$ of women with laparoscopically confirmed PID at Ngwelezana hospital ${ }^{19}$ and $60 \%$ in Durban ${ }^{20}$ when $C$ trachomatis was shown in $30 \%$, a level similar to that of a control group of family planning clinic attenders.

The incidence of $C$ albicans in this study was $27 \%$, which is similar to the incidences recorded in antinatal clinic studies in Durban ${ }^{6}$ and Harare. ${ }^{11}$ The incidence of $G$ vaginalis was $6.2 \%$, lower than that of $36 \%$ found in a Durban antinatal clinic study (AA Hoosen et al infectious diseases and STD congress, Durban 1987) and $60 \%$ in non-pregnant rural women in Botswana, ${ }^{21}$ for whom cultures were not performed.

The prevalence of syphilis in Africa remains high, ${ }^{22}$ although changing trends have been recorded in some countries. A decrease has been found in Malawi, ${ }^{23}$ but conversely a more recent increase was recorded in neighbouring Zambia. ${ }^{24}$ Rural antinatal clinic study incidences of $1.6 \%-9.8 \%$ in Mozambique ${ }^{25}$ and $12.5 \%$ in $\mathrm{Zambia}^{24}$ were similar to our figure of $11.9 \%$ (table 2). Slightly higher levels of $15-20 \%$ have been 
Table 2 Results of serological tests

\begin{tabular}{|c|c|c|}
\hline & No & $\begin{array}{l}\% \\
\text { Positive }\end{array}$ \\
\hline $\begin{array}{l}\text { Syphilis } \\
\text { Hepatitis B surface antigen (HBsAg) } \\
\text { Antibody to human immunodeficiency virus } \\
\text { (HIV) }\end{array}$ & $\begin{array}{r}23 \\
8 \\
0\end{array}$ & $\begin{array}{r}(11.9) \\
(4 \cdot 1)\end{array}$ \\
\hline
\end{tabular}

recorded for antinatal clinic attenders in South Africa. ${ }^{12627}$ The absence of physical signs in our patients with positive syphilis serology results probably reflected the widespread use of benzathine penicillin by local primary health care workers as the first line treatment for any STD, including vaginal discharge. Endemic syphilis has been recognised in the Karoo, North Western Cape, and Orange Free State ${ }^{28}$ areas of South Africa as recently as $1985 . .^{29}$ Many of these cases were previously diagnosed as being yaws. ${ }^{30}$ In Zambia congenital syphilis affected $8.6 \%$ of infants aged under three months who required hospital admission, ${ }^{24}$ and in Durban 3.2/1000 perinatal deaths were due to syphilis. ${ }^{31}$ In South Africa repeat syphilis serology testing is recommended, as infection may be acquired later in pregnancy. ${ }^{27}$

The $4 \cdot 1 \%$ incidence of $\mathrm{HB}_{5} \mathrm{Ag}$ was consistent with the results from different tribal groups in South Africa, in whom horizontal transmission is implicated, and incidence range from $2 \cdot 1 \%$ to $15.8 \% .^{3233}$

Despite the increasing evidence of heterosexual transmission of HIV infection in local blood donors ${ }^{34}$ and STD clinic attenders, ${ }^{35}$ no patients with antibody to HIV were found. In sub-Saharan Africa lower incidences are found in rural areas, ${ }^{36}$ an incidence of less than $1 \%$ was recorded in rural area 15 kilometres away from Nairobi, ${ }^{37}$ where $52 \%$ of prostitutes had antibodies. $^{38}$

The incidence of $T$ vaginalis was $49 \cdot 2 \%$, one of the highest recorded in the world, similar to that in Durban, and higher than that found in the Gambia $(23 \%),{ }^{7}$ Swaziland $(23 \%){ }^{39}$ and urban areas in Cameroon $(21 \%),{ }^{40}$ Nigeria $(21 \%),{ }^{41}$ and Zimbabwe $(31 \%){ }^{42}$ Vaginal trichomoniasis has not been associated with adverse perinatal outcome in Africa, ${ }^{434}$ but low gestational age and birth weight have been found linked with it in the USA. ${ }^{45}$

Cytological evidence of human papillomavirus (HPV) infection was found in $11(5.7 \%)$ women, five of whom had cervical dysplasia. In Zimbabwe genital warts have been found in $10.2 \%$ of antinatal clinic attenders, ${ }^{11}$ and South Africa and South West Africa have the highest incidences of HPV and cervical intraepithelial neoplasia yet recorded ${ }^{46}$ Abnormal cytology results were found in $20(10.4 \%)$ of our patients, but none had clinically detectable warts. Carcinoma of the cervix has long been recognised as a problem in South Africa, ${ }^{47}$ the incidence in Natal being the third highest in the world. ${ }^{48}$

These results show that the incidences of STDs in this rural community were similar to those in urban South African patients. Socioeconomic conditions dictate that men from rural areas seek work in the cities or are engaged in contracts further afield, but return regularly to their home districts and probably act as vectors of STD. The implications for disease control are that health education programmes in rural areas should include STD material, and antenatal clinic attenders should be a specific target group. Given the low health care budget afforded to this population, allocation of health care resources to the field of STDs has been minimal. The incidence of STDs found in this study are unacceptably high and warrant urgent action, particularly now that black heterosexuals in Natal are the group at highest risk of acquiring HIV infection in South Africa and STDs are accepted as playing a major part in the transmission of HIV. ${ }^{49}$

\section{References}

1 Antal GM. The epidemiology of sexually transmitted diseases in the tropics. In: Osaba AO, ed. Clinical tropical medicine and communicable diseases. London: Ballière, 1987; Vol 2:1-16.

2 Klopper JM, Taylor SP. The health and wealth of South Africa. $S$ Afr Med J 1987;72:799-801.

3 Philip A, Carter-Scott P, Rogers C. An agar culture technique to quantitate Trichomonas vaginalis from women. $J$ Infect Dis 1987;155:304-8.

4 Totten PA, Amsel R, Hale J, Piot P, King KK. Selective differential human blood bilayer media for isolation of Gardnerella (Haemophilus) vaginalis. J Clin Microbiol 1982;15: 141-7.

5 Young H. Cultural diagnosis of gonorrhoea with Modified New York City (MNYC) medium. British Journal of Venereal Diseases 1978;54:36-40.

6 Hoosen AA, Ross SM, Mulla MJ, Patel M. The incidence of selected vaginal infections among pregnant urban blacks. $S$ Afr Med J 1981;59:827-9.

7 Mabey DC, Thomas K. Genital infections with Chlamydia trachomatis and other pathogens among women in a rural Gambian village. African Journal of Sexually Transmitted Diseases 1986;2:19-20.

8 Arya OP, Nsanzumuhire H, Taber SR. Clinical, cultural and demographic aspects of gonorrhorea in a rural community in Uganda. Bull WHO 1973;49:587-95.

9 Galega FP, Haymann DL, Nasah BT. Gonococcal ophthalmia neonatorum: the case for prophylaxis in tropical Africa. Bull WHO 1984;62:95-8.

10 Bentsi C, Klufio CA, Perine PL, et al. Genital infections with Chlamydia trachomatis and Neisseria gonorrhoea in Ghanaian women. Genitourin Med 1985;61:48-50.

11 Latif AS, Bvumbe S, Muongerwa J, et al. Sexually transmitted disease in pregnant women in Harare, Zimbabwe. Southern African Journal of Sexually Transmitted Diseases 1985;5:13-6.

12 Welgemoed NC, Mahaffey A, van den Ende J. Prevalence of Neisseria gonorrhoea infection in patients attending an antenatal clinic. $S$ Afr Med J 1986;69:32-5.

13 Hoosen AA, van den Ende J, Kharsany AB. The aetiology of acute urethritis in black males in Durban, South Africa and penicillin susceptibility of Neisseria gonorrhoeae isolates. Southern African Journal of Epidemiology and Infection 1987;2:4-6. 
14 Méheus A. Gonorrhoea. In: Osaba AO, ed. Clinical Tropical Medicine and Communicable Diseases. London: Ballière, 1987; Vol 2:17-31.

15 Mabey DCW, Lloyd-Evans NE, Conteh S, Forsey T. Sexually transmitted diseases among randomly selected attenders at an antenatal clinic in The Gambia. British Journal of Venereal Diseases 1984;60:331-6.

16 Darougar S, Forsey T, Osaba AO, Dines RJ, Adelusi B, Coker GO. Chlamydial genital infection in Ibadan, Nigeria: seroepidemiological survey. British Journal of Venereal Diseases 1982;58:366-9.

17 Laga M, Plummer FA, Nzanze $\mathrm{H}$, et al. Epidemiology of ophthalmia neonatorum in Kenya. Lancet 1986;ii:1145-9.

18 Burchell HJ, Cronje HS, De Wet JI. Efficacy of different antibiotics in the treatment of pelvic inflammatory disease. $S$ Afr Med J 1987;72:248-9.

19 Allen LA, Schoon MG. Diagnostic laparoscopy and management of patients with confirmed acute pelvic inflammatory disease. $S$ Afr Med J 1984;65:201-2.

20 Hoosen AA, Quinlan DJ, Kharsany ABM, Moodley J, van den Ende J. Sexually transmitted pathogens in acute pelvic inflammatory disease. $S$ Afr Med J (in press).

21 Petersen J, Homan M, Fehler HG, Ballard RC. The microbiology of vaginal discharges in non-pregnant rural Botswanian women. Southern African Journal of Sexually Transmitted Diseases 1985;5:59-62.

22 Osoba AO. Sexually transmitted diseases in tropical Africa. British Journal of Venereal Diseases 1981;57:89-94.

23 Rampden F. Veneral syphilis in tropical Africa. British Journal of Venereal Diseases 1978;54:364-8.

24 Ratnam AV, Din SN, Hira SK. Syphilis in pregnant women in Zambia. British Journal of Venereal Diseases 1982;58:355-8.

25 Liljestrand J, Bergstrom S, Nieuwenhuis F, Hebestedt B. Syphilis in pregnant women in Mozambique. Gentourin Med 1985;61:355-8.

26 Mahomed MF, Mokaila PP, Barron C, Crewe-Brown HH. The prozone phenomenon in syphilis serology in antenatal patients. Southern African Journal of Sexually Transmitted Diseases 1984;4:29-31.

27 van Schalkwyk L, van den Ende J. Serologiese toetsing vir sifilis tydens swangerskap. Southern African Journal of Sexually Transmitted Diseases 1985;5:3-5.

28 Scott FP, Lups JG. Endemiese sifilis. $S$ Afr Med $J$ 1973;47: $1347-50$.

29 van Niekerk CH, van Niekerk LC, van den Ende J. Positiewe serologiese toetse vir sifilis by swart laerskoolkinders van Bloemfontein. S Afr Med J 1985;67:90-1.

30 Murray JF. Endemic syphilis or yaws? S Afr Med J 1957;31:821-4. 31 Ross SM, MacPherson T, Wallace J. Unsuccessful pregnancies- report on 200 perinatal postmortems. $S$ Afr Med J 1978;54: 828-9.

32 Botha JF, Ritchie MJ, Dusheiko GM, et al. Hepatitis B virus carrier state in black children in Ovamboland: role of perinatal and horizontal infection. Lancet 1984;i:1210-3.

33 Bersohn I, MacNab GM, Pyzikowska J, Kew MC. The prevalence of hepatitis B (Australia) antigen in southern Africa. S Afr Med $J$ 1974;48:941-4.

34 Schoub BD, Smith AN, Lyons SF, et al. Epidemiological consideration of the present studies and future growth of the acquired immunodeficiency syndrome epidemic in South Africa. S Afr Med J 1988;74:153-7.

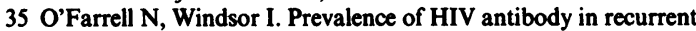
attenders at a sexually transmitted disease clinic. $S$ Afr $M e d J$ 1988;74:104-5.

36 Anonymous. AIDS in Africa. [Editorial]. Lancet 1987;ii:192-4.

37 Mason JC, Bruce RB, Azadian BS, Wall RA. HTLV-III antibody in East Africa. $N$ Engl J Med 1986;315:259-60.

38 Kreiss JK, Koech D, Plummer FA, et al. AIDS virus infection in Nairobi prostitutes. $N$ Engl J Med 1986;314:414-8.

39 Méheus A, Friedman F, van Dyck E, Gruyver T. Genital infections in prenatal and family planning attenders in Swaziland. East Afr Med J 1979;57:212-7.

40 Nasah BT, Nguematcha R, Eyong M, Godwin S. Gonorrhoea, trichomonas and candida among gravid and non-gravid women in Cameroon. Int J Gynaecol Obstet 1980;18:48-52.

41 Osoba AO, Onifade A. Venereal diseases among pregnant women in Nigeria. West African Medical Journal 1973;22:23-5.

42 Mason PR, Patterson B. Epidemiology and clinical diagnosis of Trichomonas vaginalis infection in Zimbabwe. Centr Afr J Med 1983;29:53-5.

43 Mason PR, Brown I McL. Trichomonas in pregnancy. Lancet 1980;ii:1025-6.

44 Ross SM. Trichomonas vaginalis-a review. Southern African Journal of Sexually Transmitted Diseases 1982;2:2-6.

45 Hardy PM, Hardy JB, Neil EE. Prevalence of six sexually transmitted disease agents among pregnant inner-city adolescents and pregnancy outcome. Lancet 1984;ii:333-7.

46 Markowitz S, Leiman G, Margolius KA. Human papilloma virus and cervical intra-eipthelial neoplasia in an African population. Southern African Journal of Epidemiology and Infection 1986;1:65-9.

47 Grant MCG. Carcinoma of the cervix-a tragic disease in South Africa. $S$ Afr Med J 1982;61:819-22.

48 Harrington JS. Epidemiology and aetiology of cancer of the uterine cervix. S Afr Med J 1975;49:443-5.

49 Department of National Health and Population Development. I, AIDS Update, Part 3. Epidemiological Comments. 1988;15: $1-28$. 